\title{
Pareto's legacy in modern economics. The case of psychology
}

\section{Luigino Bruni}

\section{(2) OpenEdition}

1 Journals

Electronic version

URL: http://journals.openedition.org/ress/759

DOI: $10.4000 /$ ress.759

ISSN: 1663-4446

\section{Publisher}

Librairie Droz

\section{Printed version}

Date of publication: 1 July 2010

Number of pages: 93-111

ISBN: 978-2-600-01449-6

ISSN: 0048-8046

\section{Electronic reference}

Luigino Bruni, «Pareto's legacy in modern economics. The case of psychology », Revue européenne des sciences sociales [Online], XLVIII-146 | 2010, Online since 01 July 2013, connection on 30 April 2019. URL : http://journals.openedition.org/ress/759; DOI : 10.4000/ress.759 


\section{PARETO'S LEGACY IN MODERN ECONOMICS THE CASE OF PSYCHOLOGY}

\section{INTRODUCTION}

In the late 19th century, neoclassical economics (the economics of rational choice and maximisation) developed. Originally, neoclassical economics was grounded on utilitarian psychology - the assumption that there exists a onedimensional, interpersonally comparable measure of mental states ('pleasure'), and the hypothesis that rational individual choice was maximisation of this measure. But some embarrassment about the fact that this measure had never been found: not clear why we should expect to find such a measure.

In the 20th century, economists abandoned the utilitarian assumptions but retained most of the theoretical structure that had originally been derived from those assumptions: the foundations of the theory were changed, but the superstructure was kept. The new foundations were postulates about preferences, or about choices; rationality was construed as consistency of preference or of choice - and not, as before, instrumental rationality (in pursuit of pleasure).

Pareto is generally regarded as the prime instigator of this switch, and mainstream rational choice theory - Hicks, Allen, Samuelson... - has followed, although re-interpreted, Pareto's epistemological foundations of microeconomics. Pareto is therefore at the crossroad of contemporaries theories of choice: both the standard approach and the critical ones can be fruitfully analysed compared with the ideas of Pareto on this issue. In particular, in this paper the comparison is done by means of the role of psychology in Pareto's theory: Pareto having finding that the psychological theory beyond economics lacked support, instead of looking for better psychological foundations (i.e. conserve the question, look for the correct answer) changed the interpretation of the foundations (i.e. conserve the answer, look for a different question which will make it correct).

Between the end of 1899 and early 1900, Pareto, breaking away from the first generation of marginalists-hedonists, pursued two fundamental and distinct objectives, to be considered his main legacy to contemporary economic science:

a) ordinalism, or the replacement of a cardinal by an ordinal utility function, by transforming the Cardinalist Edgeworth's indifference curves into ordinal ones;

b) the interpretation of ophelimity as an index of preferences, or the emancipation of his theory of choice and equilibrium from hedonism. In the turning point of 1899 Pareto built up his economic theory on «the naked fact of choice», 
without having to resort to important measuring and not even to the existence of utility (Pareto, 1984, pp. 290-291) ${ }^{1}$.

With these goals he achieved only a part of his project, the part he considered the easiest. In the 30's Hicks, Allen, Samuelson and others rediscovered Pareto's theory of choice. In a atmosphere of behaviourism, operationalism and neopositivism, Pareto was presented as the founder of a new economic science, based on facts, free from unobservable metaphysical categories such as pleasure and utility.

Although this is a very well-known story, it is not the whole story.

In fact, in this reading of Pareto the image that emerges is that of an uncertain, confused and almost schizophrenic author. He was regarded as a talented precursor, who, however, created a hybrid, something halfway between the old and the new. Hicks sums this up succinctly:

\begin{abstract}
even after Pareto had established his great proposition, he continued to use concepts derived from the earlier set of ideas. The reason was, perhaps, that he did not take the trouble to rework his earlier conclusions in the light of a proposition, which he only reached at a rather late stage of his work in economics. However that may be, he missed an opportunity (Hicks 1939 [1946], p. 19).
\end{abstract}

Hicks and Allen immediately began speaking of an incomplete Paretian revolution, basing their argument on the many passages in which Pareto used concepts which were still based on cardinalist and utilitarian categories.

During the following decades, many historians and economists went back to the viewpoint of Hicks, and still continue to make the same assessments.

After having demonstrated that Pareto systematically made use of a cardinal idea of utility (ophelimity), Oskar Lange asked himself: 'Was it inconsistent of Pareto to keep these definitions in spite of regarding utility as immeasurable?' (Lange 1934, p. 218), and after a lengthy and detailed analysis, he concludes that the answer was yes. The same evaluation can be found in Stigler and in Samuelson: 'Pareto was inconsistent' (Stigler 1950, p. 389; Samuelson 1974, p. 1256) ${ }^{2}$.

To those authors who interpret his work, the very fact that Pareto continued referring to a cardinal idea of ophelimity also confirms the argument that Pareto continued to adopt a hedonistic philosophy despite claiming to have overcome the 'hedonistic season' in economics. Therefore, from the 1930s, Pareto's main achievements as regards the theory of utility, were accused of being inconsistent.

In previous works I have tried to demonstrate that within the context of his philosophy of science, Pareto's theory of choice is not inconsistent but, rather, much more complex, profound and more sophisticated than the interpretations of his work that have been attempted.

In this paper I intend to show that Pareto's theory of choice is much more complex than his Anglo-Saxon rediscovers thought. Pareto's theory of choice presents open questions, but they are different than the mainstream interpretation thinks.

1 Letter to Pantaleoni of January 1899 (in Pareto, 1984, II, pp. 290-291).

2 Recent papers which confirm this assessment are those by Lewin (1996, p. 1309), and Drakopoulos (1991, p. 110). 


\section{PARETO'S REVOLUTION AND THE BIRTH OF MODERN RATIONAL CHOICE}

\subsection{Pareto's theory of action}

Towards the end of the 19th century, Pareto began teaching sociology at the University of Lausanne, and, just like what happened a few years earlier with economics, «having to teach it - he wrote to Antonucci - made me study it better, and I realised that many of my theories had to be modified to become scientific » [Pareto (1975), p. 614].

Already during the first months of this new study, Pareto individualises the focal idea of his sociology, the theory of logical and non-logical actions; this was a theory that revealed itself as being the key to a new and scientific reading of all of history. The social dynamics is governed by two great forces: the logical ones, easily studied, yet rare and limited to a very restricted circle (individual and logical actions); and by the non-logical ones, the vast majority, studied with great difficulty because we cannot, by definition, apply that type of logic, which is mathematics to them and because they have never been studied [Pareto (1900b), p. 162] ${ }^{3}$.

In order to understand Pareto's revolution in economics in all its implications with respect to human interactions, we must look at his philosophy of science. In line with Mill's methodology ${ }^{4}$, economics, to Pareto, only studies a small part of the human behaviour. There is also another aspect, «born of non-logical actions, which also need to be studied. Here difficulties begin to arise» (Pareto, 1900b, p. 162). In this assertion, we can find a synthesis of Pareto's methodology of action.

A real action presents two main components:

a) the logical component, based on a pure instrumental reasoning, where the means are adequate to the end, subjectively and objectively;

b) the non-logical one, where non-logical does not mean illogical or irrational but just based on a different type of logic, as Pareto many times has specified ${ }^{5}$.

Economics deals with the logical part, and its work is simple. Sociology deals with the rest, and its work is very difficult. To study the non-logical part of an action, to understand the phenomenon: this was the main challenge Pareto confronted for the rest of his life. Only within his epistemology is it possible to fully comprehend Pareto's analysis of action.

The foundation of his methodology is in fact the use of the method of analysis and synthesis: to decompose the complex action into its parts, investigate each separately, and attempt a synthesis - for Pareto synthesis means «sociological synthesis ».

3 This is also the meaning of chapter III of the Treatise on General Sociology (1916) and the severe criticism turned against many of the important authors of the past, among which Spencer, Comte and Mill: as soon as the researchers caught a glimpse of non-logical actions they would immediately turn back to the logical ones.

4 On the strict methodological similarity between Pareto and Mill see Bruni and Guala (2001).

5 The best and more complete definition of Pareto's theory of logical and non-logical actions can be found in Pareto (1916), $\S \S 150-152$. 
In establishing the boundaries between the economic and the social spheres of human action, Pareto used the logic of action as criterion.

Pareto, furthermore, specified that pure economics deals not only with logical action but also with self-centred «choices that the individual makes considering solely the things that he prefers », omitting, or better yet, turning over to sociology, actions «that the individual makes considering the effects that these choices will have on other individuals » (Pareto, 1900a, p. 223).

In the theory of logical and non-logical actions, he believed that he had found the path across which he would give his own personal and main contribution to the history of social science.

Here too, the idea itself is not new, yet Pareto wanted to be the first one to apply it to social science.

Therefore, according to Pareto, in order to understand human action and thus the social system, one must analyse and then synthesise study the logical and nonlogical aspects separately, and then put them back together again in the synthesis ${ }^{6}$. Without this synthesis, human action cannot be understood, neither in the economic field (where the logical aspect prevails), nor in the non-economic field.

To Pareto economics deals with a very narrow slice of human and social life: if you would understand the social action you must study separately the logical and the non-logical part of it: the two parts are based on two completely different kind of rationality, which cannot be reduced to one unique genre. The impossibility of a universal logic of choice was the message lanced by Pareto to the social sciences: a message that, despite the standard historiography, was completely missed by his «followers».

\subsection{The modern Rational Choice Theory : an escape from Pareto?}

The birth of the modern Rational Choice Theory normally begins with the «theory of choice» of Pareto, whose results were re-proposed and publicised in 1934 by John Hicks and R.G.D. Allen, the protagonists of the real 'ordinalist revolution' which replaced traditional utilitarianism with the modern consumer theory. From the late thirties onwards Paul Samuelson in a series of works took the ordinalist revolution to the extreme with his 'revealed preferences' approach. The mathematical economists of the fifties finished the job.

However, in this paper I would like to emphasise just one point: that there is a radical difference between Pareto's theory of action and those of Hicks and contemporary microeconomics, a difference that is very much related to contemporary analysis of personal interactions ${ }^{7}$.

6 The method of Analysis and synthesis may be found in the first chapter of his Manuel of Economic Politics: «abstraction is, for all the sciences, the preliminary and indispensable requirement for all research. (...) When we return to the concrete from the abstract, the parts which had been separated in order to study them better must be united again » (Pareto, 1971 [1906], I, §§ 20; 26). In fact, the analysis of other kinds of social interactions, based on a non-instrumental rationality, is present in his Sociology. For example the «residues of the fourth class» (Residues in relation with sociality: Pareto, 1916, $\S \S 113-1206)$, are entirely dedicated to «the want for sociality».

7 For a broader analysis of the continuity or discontinuity between Pareto and the microeconomics of the thirties see Bruni and Guala (2001). 
In a 1934 paper with Roy Allen, Hicks, under the influence of the neopositivistic philosophy, wrote: «The methodological implications of [the new] conception of utility [...] are far-reaching indeed. By transforming the subjective theory of value into a general logic of choice, they extend its applicability over wide fields of human conduct (Hicks e Allen, 1934, p. 45, my italic).

The same concept is restated in Value and Capital:

that there are a great many such extensions appears at once when we consider how wide is the variety of human choices which can be fitted into the framework of the Paretian scale of preference (Hicks, 1939, p. 24).

It is a methodological attitude very close to that of Wicksteed. In fact, in reviewing Pareto's Manuel (1906), Wicksteed criticised the book for having restricted the domain of economics, which, for Pareto, makes up «a very small part of the actual phenomena of the business» (Wicksteed, 1906, p. 817). But above all, according to Wicksteed, Pareto does not realise that his «curves of indifference » can cover a much greater area of human behaviour.

Obviously, as seen, Pareto had a completely different idea of action. He realised that economic laws explained a small part of human behaviour. The kinds of logic behind economic and non-economic actions are substantially different. To utilise the structure of the theory of choice presupposes in Pareto's approach that agents are performing logical actions. This is very clear in all his scientific work ( «What everybody surely knows, since here we are dealing with logical action, is that...» Pareto, 1898, p. 128, my italic).

In fact the theory of choice was introduced by Pareto in 1900, after having developed his theory of logical and non-logical actions. His theory of economic action before 1900 was still based on pleasure.

In the Manual, Pareto clearly specifies that his whole economic theory is valid for «many logical, repeated actions which men perform to procure the things which satisfy their tastes » (1971 [1906], III, § 1). Therefore, it is not strange either that we don't find indifference curves in his Sociology, or that he has devoted the second half of his life to study Sociology, to write his cyclopic Treatise, in order to understand the dynamics and laws of the different «kind of logic» which governs the great part of actions. Only after having written a scientific sociology, a scientific analysis of the non-logical part of the action, Pareto would have completed his project, that is to write a «Treatise on synthetic economics», which would be able to combine the logical and non-logical elements present in every economic action. He never completed such a book, and nobody has followed Pareto in this project $^{8}$.

\section{THE «PARADOXES» OF PARETIAN THEORY OF ACTION}

The methodological fundamentalism, i.e. the a-priori conviction that only the natural method of analysis and synthesis, combined with the «naked fact of choice», is the scientific method for every inquiry, brought Pareto to some

8 See Bruni (1997b). 
paradoxes in aspects very central in his economic theory, that is the foundation of his indifference curves, which means the whole theory of choice and the general equilibrium analysis built on it.

Let us see why.

First of all, Pareto, in the ch. III of the Manual states that «we will study the many logical, repeated actions which men perform to procure the things which satisfy their tastes » $(\S 1)$.

A such a theory of logical actions poses two main problems: the so-called integrability problem, and the role of psychology in economics.

\subsection{The Integrability Problem}

Logical action in Pareto's system includes the ordinary economic activities of consumers, not just the businessman we heard about before. Notice also that Pareto here is taking it as given that 'tastes' and 'desires' exist in a form which gives rise to a maximisation problem with a correct answer, which can be learned by trial and error.

This issue is an expression of Pareto's version of the integrability problem.

In plain words (without too much technicalities), Pareto's version of integrability problem (that is quite different from the standard one: see Chipman et al 1971) is quite easy. The slope of indifference curves can be, theoretically o «imaginary» (Pareto only imagines that the agent, interrogated, will give the answers that economists need to know: but, in reality, there are no economist, no agents, no real experiments: only imaginary ones ${ }^{9}$ ), deduced from all possible bundles of goods from budgetary data, being

$$
\frac{M g U X_{1}}{M g U X_{2}}=\frac{P X_{1}}{P X_{2}}
$$

Then Pareto thought to be possible to obtain empirically the differential equation of the indifference lines: can we integrate it in order to obtain the equation of indifference lines? Mathematically the issue is: does the integral line $f\left(x_{1}, x_{2}, x_{3}, \ldots\right) d x_{1}+g\left(x_{1}, x_{2}, x_{3}, \ldots\right) d x_{2}=0$, exist independently of the path between the beginning and end points? If the preferences system displays a proper continuity, the equation is integrable.

But if we, like Pareto, want that the entire theory «rest only on experience», on choices, nobody ensures us of the existence of continue and differentiable lines of indifference. Economically it is to demonstrate that the choices «that an individual makes between combinations of goods differing by infinitesimal amounts [will] be consistent with the choices he makes between combinations differing by finite amounts. For example, the individual starts with the combination 100X1, $100 X 2,100 X 3$. By infinitesimal steps we obtain an infinite number of combinations, each equivalent to the preceding, reaching ultimately the combination $90 \times 1,85 \times 2,120 \times 3$. Will the individual consider this last combination equivalent to the first?» (Stigler 1950 [1965], pp. 122-123).

Pareto first mentioned the so-called «integrability problem» in a letter to Pantaleoni (December 1891), where he refers to Antonelli (1886), who can be

9 On this issue see Mayer (1932), and Moscati (2001). 
rightly considered as the first economist who has stated the integrability problem in economic terms ${ }^{10}$.

Pareto had dealt with the integrability problem in the Considerazioni (189293), where he still used the cardinal indifference curves (à la Edgeworth), and in a footnote, he specified that only 'when there are only two goods, the equation [of the lines of indifference] can always be integrated' (Pareto 1892-93 [1982], p. 299, footnote). In the Cours (1896) we find again this specification, that, however, he forgot in the Manual, and the Italian mathematician Vito Volterra (1906, p. 300), gently reminded it to him.

In fact, in an overall positive review to the Manual, Volterra 'performed one of the few services professional mathematicians have ever rendered to economy theory' (Samuelson 1950, p. 355), pointed out that: a) in the case of only two goods, there will be an infinite number of equations whose indifference curves represent the same preferences (that is there is an infinite number of integrating factors to the differential equations); b) if the goods are independent, that is the ophelimity of the good $\mathrm{A}(\mathrm{Fa})$ is only a function of a and $\mathrm{Fb}$ is only the function of $b$ (hypothesis of separateness), then in cases a) and b) we reach a unique function that certainly exists; c) in the case of more than two goods, the problem is more complicated because a trinomial (or a greater number of terms) differential equation could not admit a differential factor.

Volterra's annotation was greatly appreciated by Pareto, and it provoked first the article L'ofelimità dei cicli non chiusi (Pareto 1906 [1982]), a paper written by starting from an analogous problem in thermodynamics with open and close cycles (only the closed cycles conserve the potential energy), and then provoked some of the variations embodied in the Mathematical Appendix of the French edition of the Manual in the 1909. Pareto's integrability problem is mainly known in the history of economics for a mistake he made in identifying the order of integration with the order of consumption, that caused even sarcastic jokes ('I don't know whether he drinks his beer before his whisky or his whisky before his beer': Samuelson 1950, p. 361). Truly, in the dialogue with Volterra, Pareto despite Volterra's emphasis on mathematical conditions for the integrability of indifference lines, and Pareto confusion between the order of integration and the order of consumption, the real issue behind was just about the question of defining a utility function over consumption paths (that are derived directly from 'experience'), and, more deeply, a problem of transitivity in choices: «The correct translation of the integrability problem was in terms of the consistency of consumer preferences » (Stigler 1950, p. 124) $)^{11}$.

John Hicks accused Pareto of having spent to much energy on the 'mysterious theory of open and closed cycles', a problem that, according to Hicks, 'fascinates mathematicians, but it does not seem to have any economic importance at all' (1939 [1946], p. 19, footnote 1). The English economist attributed this error to the

\footnotetext{
${ }^{10}$ Pareto sarcastically asserts that 'Antonelli went right into the clouds' (1984 [1960], I, p. 121), but, actually, Antonelli was not only the first who dealt with the integrability problem, but also the first who used the theory of 'open and closed cycles' of thermodynamics in the analysis of economic problems, just as Pareto would do a few years later.

${ }^{11}$ See also Demaria (1962), pp. 505-514.
} 
fact that Pareto never went back to 'rework his earlier conclusions' (Ivi, p. 19): perhaps Hicks missed the methodological meaning behind this factor of integration.

In fact the integrability problem became extremely important for Pareto, and he dedicated a good part of his energies to it in his last works on pure economics (Pareto 1911 [1982], pp. 597, 614). The demonstration of the conditions for the integration of the indifference curves was a necessity for his 'experimental' program: to start, at least theoretically, directly from the indifference curves in pure economics, and from that build the system of general economic equilibrium.

Samuelson too, like Hicks, misunderstood that the serious economic problem discussed by Pareto from 1906 on was not the 'technical' integrability problem, rather the measurability of utility, starting from empirical data (indifference curves), a core issue of his experimental research project. This is very clear as soon as one reads Pareto's article on open and closed cycles, which, despite the intention of Volterra of turning Pareto's attention towards the technicalities of the integrability problem, is almost entirely devoted to the measurability of (ordinal) utility.

Therefore, although Hicks' and Samuelson's criticism to Pareto's confusion is right as far as the integrability problem strictu sensu is concerned, both of them, however, did not understand that Pareto's aim in that 'problem' was another one, that is the old purpose of expelling the metaphysical utility from economic theory ${ }^{12}$.

Pareto was aware that there is a deep problem in his project of expunging the metaphysical from economics, namely how justify the assumption that indifference curves exist, when all we have to go on are the facts of experience. If this problem can't be solved, he can be accused of helping himself to an assumption about economic behaviour (transitivity) which depends for its rationale on 'metaphysical' arguments about the internal properties of utility.

Therefore, Pareto's integrability problem is very much related to the role of psychology in the theory of rational choice ${ }^{13}$.

12 Even Samuelson in 1938, in his first article on 'revealed preferences', defines the problem of integrability as a 'puzzling' theme he had 'little to say' about (Samuelson 1938, p. 68). This is not the right time to investigate how Samuelson dealt later, in 1950, with the problem of integrability. Only a mention of the fact that he too (like Stigler 1950) demonstrated that Pareto confused the integrability problem with the problem of the order of consumption, which in fact is a pseudo economic problem.

${ }^{13}$ The greatest debate on the integrability problem occurred after the publication of Mirowski's More Heat than Light (1989). Mirowski gave another interpretation of Pareto's integrability problem (with which I cannot agree), seeing it as a proof that Pareto was the 'most ruthless proponent of the physical metaphor' (p. 221). To Mirowski the 'problem of integrability, far from being merely an arcane game played by a small coterie of mathematicians, was (and still is) the key to the understanding and evaluation of the neoclassical cooptation of the physics metaphor' (p. 250). According to Mirowski it 'is not to Pareto credit that he took the metaphor of a path too literally, associating it with the effect of the temporal order of consumption of particular commodities. His example of the order of consumption of soup and roast beef made the problem sound trivial, an opinion he himself expressed in the first page of the paper. The triviality of the problem derived from Pareto's interpretation, however, and not from the intrinsic character of the problem' (p. 249). Mirowski's thesis on the integrability - which is linked to the main thesis of the book, i.e. neoclassical theory as a 'wholesale' metaphorical appropriation of the analytical structure of mid-nineteenth century physics, a theme that goes beyond the evaluation of Pareto, and beyond the scope of this book too - has been discussed by several economists, such as Hands (1993) and Carlson (1997). Cf. also Malinvaud (1993) and Kirman (1999). 


\subsection{The debate on Psychology and Economics in the fist marginalist economists}

When Pareto looked upon economic science, the mainstream methodology, the English one above all, conceived economic science as a deductive science, built on a priori laws drawn mainly from introspection ${ }^{14}$.

Psychological introspection was seen as the possibility of pinpointing the laws that regulate economic activity (such as the desire for wealth). On these laws the economist began constructing an abstract, positive and deductive economic science autonomous to the other branches of knowledge, even if connected to them.

An interesting question is whether economics felt the influences of the methodological changes that occurred in psychology with the birth of modern experimental psychology, after 1860s.

The German Gustav T. Fechner and before him E.H. Weber upheld the fundamental thesis (and revolutionary at that time) of the possibility of measuring mental phenomena, since the laws that govern the relationship between mid and body could be individualised in a quantitative relationship between mental sensations and material stimuli.

Fechner clearly asserted the possibility of empirically measuring sensations, which developed the important research program known as psychophysics (the word is self-explanatory: the science of the relationships between the mental and the material world). The result that came from his research went into a textbook in 1860 (Elements of psychophysics), a book often considered as the birth of psychology, rightly on the eve of the «marginalist revolution». The program begun by Fechner was then continued by Wilhelm Wundt (1852-1920), another German scientist considered the true father of experimental psychology as an autonomous discipline, with the publication of his Principles of Physiological Psychology (1873-74), the very same years of the marginalist turning point (the power of dates! And of the cultural climate!). Wundt made his experiments in a laboratory under tight experimental conditions, and classified the sensations on the basis of their intensity, duration and the modality of the sense (the links with the theory of utility of Jevons and Edgeworth can be noted immediately), where we can also see a similarity with the characteristics of pain and pleasure of Beccaria and Bentham: duration, intensity, certitude and proximity. He then formulated a three-dimensional theory of sentiments (pleasure-displeasure, tension-relaxation, excitement-depression), but in this he was less followed by other economists who based their own theories on the mono-dimensional utility (pleasurepain).

Although many marginalists considered Fechner's law similar to the «Bernoulli's hypothesis » on the diminishing marginal utility of money, these two theories must be kept distinct. In 1713 Daniel Bernoulli, in his studies on probability, gambling and insurance, shown that equal increment of gain yields an advantage which is inversely proportional to individual's wealth:

${ }^{14}$ This is the position held by Mill (Mill 1843 [1862], II, p. 508), and later by Jevons, Cairnes, or Pantaleoni, a position masterly synthesised by J.N. Keynes (1891)[1963] in a work that can be considered the icon of the methodology of the first generation of marginalists. 


$$
d U=k \frac{d x}{x}
$$

where $d \mathrm{U}$ is the increment of utility resulting from an increment $d x$ of wealth (x) ( $\mathrm{k}$ is a constant). From that follows that total utility is a logarithmic function of wealth:

$$
U=k \log \frac{x}{c}
$$

(c is the subsistence consumption) ${ }^{15}$. Bernoulli's line of research « was joined by the independent series of researches that culminated in the Weber-Fechner law » (Stigler 1950 [1965], p. 113). Weber-Fechner law, or simply Fechner law tells that

$$
S=C \log \frac{R}{R_{0}}
$$

the just «noticeable increment to any stimulus is proportional to the stimulus » (Ibid.), and it can be written as it follows:

(where $\mathrm{S}=$ sensation, $\mathrm{R}=$ stimulus, $\mathrm{R}_{0}=$ the threshold of sensation). This law then shown the decreasing intensity of stimuli, and the consequent thesis that the effects of the intensity of stimuli are not absolute but dependent on the quantity of already existing sensations. The similitude with Bernoulli's law is great. Weber and Fechner were the founders of the «experimental psychology », that is to prove that psychological laws are based on experimental data. All this generation of psychologists based their methodology on introspection, that is the examination of one's state of mind, psychology being the science of conscious experience.

E.B. Titchener developed and then revolutionised the approach by Wundt founding, in America, the Structuralism. He felt substantially the same way about the theme of introspection, as can be seen by his Textbook of Psychology of 1909: « the method of psychology is, then, observation. To distinguish it from the observation of physical science, which is inspection, a looking-at, psychological observation has been termed introspection, a looking-within» (quoted in Schultz e Schultz 1996, p. 111).

Generally speaking, this was the state of the art in psychology during marginalist revolution.

Which, then, the relationship between the first experimental psychology and marginalist economics in the last quarter of XIX century ? If we look at marginalist book of this time it is common to find the reference to the Fechner's law, sometimes distinguished (Pantaleoni 1883) but normally associated to Bernoulli's hypothesis. But apart from Edgeworth (1881) and, in minor measure, Wicksell (in his financial economics), in the other marginalist economists (including Jevons and Pantaleoni) the reference to this psychological literature is only one further

\footnotetext{
${ }^{15}$ See Stigler 1950 [1965], pp. 110 seq.
} 
proof that their theory on decreasing of marginal utility was scientific, and they «made no real use of the theory» (Stigler 1950, p. 115).

Edgeworth deserves a special mention in this history. In his Mathematical Psychics (1881) the reference to Fecher, Wundt and the experimental psychology is important in order to scientifically justify the measurement of pleasure in his utility theory. In formulating his axiom that «Pleasure is measurable and all pleasure are commensurable» $(1881$, p. 59), he mentions that «Wundt has shown that sensuous pleasures may thereby be measured, and, as utilitarians hold, all pleasure are commensurable ... and the rate of increase of pleasure decreases as its means increase» (pp. 60, 61). Edgeworth was the marginalist economist who most took seriously the findings of experimental psychology of his time. Already in 1877 in his «New and Old methods of Ethics » he tried to found his economics on psychology, in particular on psychophysics developed in Germany few years before (Weber, Fechner and Wundt in particular). To him the results of psychophysics were the way to build economics both on hedonism and experimental facts (Fechner's law was a way - which had little success in economics - of measuring stimuli and sensations: Edgeworth applied this law for measuring pleasure and utility). When contemporary economists (such as Frank 1997) use the findings of the neurosciences in order to measure the level of happiness, they - aware or not they can be - methodologically are in continuity with Edgeworth's hedonometry.

\subsection{More at the point : Pareto and Psychology}

Pareto wrote the Cours with the problems of the «scientificity» of psychology in mind, and reached his own vision of the relationship between psychology and economics. He considered psychology as an experimental science: «the aim of this book is to construct economics on the model of the experimental sciences such as physics, chemistry, psychology» (Cours, premise).

After few years, Pareto finished his revolution on the theory of choice, which moved in the opposite direction of the contemporary psychological and economic movement. Why?

What in the 20th century has been called «the demarcation problem» (how to distinguish science from what is not?), one of the core issues of the philosophers of Vienna Circle, was of fundamental importance for Pareto. To distinguish his economics and sociology from literature («novels»), science from metaphysics, was a fundamental necessity for him.

Pareto, too simply, found the solution in the distinction between the objective (i.e. science) and the subjective (i.e. non-science). Because of this, in the economic science he made a radical choice, basing it on «objective» facts, rejecting all of the subjective and psychological dimensions in the preferences.

In Pareto the «experimental» or empirical dimension can be found, above all, in the objective verification: the external experimental data is the primary element of science for him. This is the meaning of many of Pareto's assertions, among which one mentioned in a letter to Naville: «Pure political economy therefore has a great interest in taking the least possible from the domain of psychology » (in Busino 1964, p. xxiv); or when he affirmed that one of the main conquests of the theory of choice was that «every psychological analysis is eliminated » (Pareto 1900a, preamble). 
For this reason it is not wrong to say that Pareto did in economics what in psychology did few years later the «behaviourist movement». In fact J. B. Watson, in 1913, with the publication of Psychology as the Behaviourist Views It gave birth to Behaviourism, a movement that completely broke away from the past, re-founding the psychological science on «external» bases: 'Psychology as the behaviourist point of views it is a purely objective experimental branch of natural science. Its theoretical goal is the prediction and control of behaviour. Introspection forms no essential part of its method' (Watson 1913, p. 158).

Lewin (1996, pp. 1308 seq.), in noting the great assonance between Pareto's theory of choice and the behaviourist movement, says that as the first experimental psychology had influenced the first generation of marginalist hedonist, the same behaviourism influenced the experimental turning point in economics between XIX and XX, Pareto in particular.

In reality the story is more complex. Although it is right to say that just «as Watson hoped that behaviourism would bring psychology into the natural science, Pareto hoped that ordinalism would forge economics into a science on a par with physics» (Lewin 1996, p. 1308), it is incorrect to think that behaviourism (as psychological movement) had any influence in Pareto's theory of choice or in the "Paretian economics» in the 1930s (Hicks, Samulson, Schultz ....) ${ }^{16}$. In fact Pareto wrote his new theory of choice at the end of XIX (1899), when behaviourism was still far away, and the psychology was still dominated by introspection.

What is instead surely true is that psychology and economics have been both influenced by physics, but, after a brief season of trust on Fechner' law, they followed two parallel lines, at least as far as the leading economists are concerned.

As far as psychology is concerned behaviorism had very little to do with the new consumer and demand theory of the 1930s. There were in fact (American) economists directly influenced during the 1920s by behaviorism, but this line of thought lasted only a short while. Economists such as Zenas C. Dickinson, A. J. Snow, Frank and others tried to construct a sort of «behaviourist economics», by extending that methodology from psychology to economics. In particular they intented to substitute a old, naive and «methaphysical» psychology with a experimental one. Then they criticised the first generation of economists psychologists (i.e. Edgeworth) because «their use of metaphysical notion in their explanation of inborn behaviour ... we object to the invocation of forces or implulses as the primary causes of native activity» (Snow 1924, p. 488).

This «behaviourist» attempt has left no mark in economics.

To Pareto, instead, even if psychology is substantially an experimental science and he does not exclude that one day, when knowledge will have progressed and one can start with the psychological fact, he could use psychology as a basis for his theory, nevertheless he was considering psychology more fragile (from an epistemic point if view) than the «fact of choice». Regarding Fechner, Wundt and «experimental» psychology, in the Manual he wrote: «In the great variety of

${ }^{16}$ Economists such as Hicks or Schultz had an attitude towards psychology very similar to Pareto's at his time (psychology is, or can be, scientific but economics has no interest to rest on psychology, because can reach its objectives without it). It is the same positivistic attitude and methodology (Ockham's razor). 
economic uses, there are many that are too far removed from the phenomena to which Fechner's law applies. It is better to resort directly to experience, and the latter shows us that for a great many uses or consumptions the elementary ophelimity does indeed diminish in the quantities consumed» (1971 [1909], IV, § 33).

For Pareto, basing economic and social sciences on psychology or on the fact of choice is mainly a question of the epistemological degree of confidence: the analysis of the curves of indifference is a much more secure basis, yet psychological analysis is not «non-scientific »: it is only less secure and always requires the verification of objective experience.

\section{CONCLUSIONS}

Economic theory of 1930s, thanks also to neopositivist philosophy, has followed Pareto's experimental economics: Hicks, Allen, Samuelson and many other explicitly linked their methodological approach to rational choice to Pareto's Manual, in particular to his anti-methaphisics and his ordinalism. At the same time, the standard interpretations of Pareto's economic revolution as 'incomplete' and 'inconsistent'.

I have tried to show that Pareto's viewpoint presents its own complexity, which makes it substantially different from those of his Anglo-Saxon followers of the 1930s.

The are three plausible readings of Pareto's inconsistencies:

1. A coherence has to be found at the methodological level: it is the thesis of my book;

2. Pareto is a «perfect substitute» of Hicks: all problems were just «wording»: he had in mind not «marginal utility» but the marginal rate of substitution, that does not need at all nor total neither marginal utility (a dialogue with Giovanni Vailati, dated 1901, goes against this interpretation);

3. The inconsistency is real: Pantaleoni and Edgeworth were right.

There is, however, an implausible reading of Pareto's theory of choice: to apply the «methodology of indifference curves » beyond his narrow field; in other words, transform Pareto's theory of economic choice into a general theory of human action.

In spite of Pareto, Rational choice theory, the core of mainstream economics, is becoming a general language one can use to explain any type of human interaction: from economics to politics, from culture to religion. The present methodology of economics (and physics) is characterised by 'imperialistic tendencies : they repeatedly aspire to account for almost every-thing' (Cartwright 1999, p. 1).

The economic approach to human behaviour by Becker and his school analyses all kinds of decisions by using the methodology of rational choice - maximising objective functions under constraint (Becker 1996). This approach is based on the methodological assumption of the possibility and goodness of analysing human behaviour by extending the field of action of economic theorising.

Not only has current economic science not followed Pareto in the direction indicated by his synthetic economics, but it has solved the problem of the 
complexity of action by making the field of application of economics coincide with that of intentional choice in all fields: "contemporary economics provides models not just for the prices of the rights for off-shore oil drilling, where the market meets very nice conditions, but also for the effects of liberal abortion policies on teenage pregnancies, for whom we marry and when we divorce and for the rationale of political lobbies' (Cartwright 1999, p. 1). Indeed, rational choice theory uses its tools even to explain social phenomena where different kinds of reasoning are at work; as a consequence economic rationality is increasingly enlarging its domain of application even covering every human action that deals with intentional choices: exactly the opposite of what Pareto considered to be the task of economics.

At the basis of such a methodology lies the anthropological assumption that man 'most of the time' is moved by rational calculations to pursue his own individual interests. Instead, for Pareto 'most of the time' passions, feelings, ideals that cannot be analysed by the 'logic' of economic science are what drive human beings.

The dissatisfaction of many contemporary economists - and they are constantly increasing in number - with the theory of rational choice because it fails to account for phenomena caused by 'non-logical' reasons, signifies that 'Pareto's dream' still has some very important things to tell us! Pareto's theory of action is, therefore, important not because of the answers he provides - which belong to the history of mechanical and positivistic systems of thought - but because of the questions he raises. Questions that are still very up to date.

\section{REFERENCES}

Allen R.G.D. (1932), «The foundations of a mathematical theory of exchange», Economica, 12, pp. 197-226.

Amoroso L. (1925), «L'economia pura», Giornale degli Economisti, 65, pp. 116-122.

Amoroso L. (1934), «Vilfredo Pareto», Econometrica, 1, pp. 1-21.

Antonelli G.B. (1886), Sulla teoria matematica dell'economia politica, Edizioni Fochetto, Pisa.

Asso P.F. (2001), The International Spread of Italian Economic Thought, 1750-1950, ed. by Edizioni Polistampa, Florence, forthcoming.

Asso P.F., Fiorito L. (2001), «Receptiveness, Knolowledge and Influence: the Spread of Italian Economic Thought in the United States: 1890-1940», forthcoming in Asso (2001).

Becker G. (1976), The Economic Approach to Human Behaviour, Chicago Univerity Press, Chicago. Becker G. (1996), Accaounting for Tastes, Harvard University Press, Cambridge Mass.

Bellanca N., Giocoli N., (1998), Maffeo Pantaleoni. Il principe degli economisti italiani, Edizioni Polistampa, Florence.

Bernardelli H. (1934), «Notes on the Determinatness of the Utility Function: II», Review of Economic Studies, 2, pp. 69-75.

Bernardelli H. (1938), «The End of the Marginal Utility Theory ?», Economica, 18, pp. 192-212. Bobbio N. (1963), «Vailati e Pareto », Rivista critica di storia della filosofia, July-September, pp. 464-486. Bobbio N. (1996), Saggi sulla scienza politica in Italia, Laterza, Bari.

Bruni L. (1999), Vilfredo Pareto. Alle radici della scienza economica del Novecento, Edizioni Polistampa, Florence. 
Bruni L. (2001), «Consents and Dissents: Moments of the Reception of Italian Economists in England: 1878-1938», forthcoming in Asso (2001).

Bruni L., Guala F. (2001), «Pareto and the Epistemological Foundations of Rational Choice», forthcoming in History of Political Economy (Spring 2001).

Bruni L., Sugden R. (2000), «Moral Canals: Trust and Social Capital in the Work of Hume, Smith and Genovesi », Economics and Philosophy, 16, pp. 21-45.

Bruni L., Sugden, R. (2007), «The road not taken», The Economic Journal, 117 (January), 146-173. Cartwright N. (1989), Nature's Capacities and Their Measurement, Oxford University Press, Oxford.

Cartwright N. (1999), The Dappled World. A Study of the Boundaries of Science, CUP, Cambridge.

Chipman J.S. (1976a), «The Paretian Heritage», Cahiers Vilfredo Pareto. Revue éuropeenne des sciences sociales, 14, pp. 65-173.

Chipman, J.S. (1976b), «An Episode in the Early Development of Ordinal Utility Theory: Pareto's Letters to Hermann Laurent», 1899-1902, Cahiers Vilfredo Pareto. Revue européenne des sciences sociales, 14, pp. 39-64.

Cooter R., Rappoport P. (1984), «Were the Ordinalist Wrong about Welfare Economics?», Journal of Economic Literature, 22, pp. 507-530.

Cressati C. (1985), «Vilfredo Pareto e John Stuart Mill», Il pensiero politico, 1/85, pp. 39-54.

D’Aspremont P., e P. Mongin (1997), Utility Theory and Ethics. CORE Discussion Paper 9663, Université Catholique de Louvain, Louvain.

De Marchi N. (1986), «Discussion: Mill's Unrevised Philosophy of Economics: A Comment on Hausman », Philosophy of Science, 53, pp. 89-100.

De Viti de Marco A. (1934), Principii di Economia Finanziaria, Eianudi, Turin.

Demaria G. (1939), «Valore e capitale nella teoria dinamica», Giornale degli Economisti, 79, pp. 770-5.

Donzelli F. (1997), «Pareto's Mechanical Dream », History of Economic Ideas, 5, pp. 127-178.

Drakopoulos S.A. (1991), Values and Economic Theory: the Case of Hedonism, Aldershit, Averbury.

Duesenberry J. (1960), «Comment on 'An Economic Analysis of Fertility'», Dempgraphic and Economic Change in Developed Countries: A Conference of the Universities-National Bureau Committee for Economic Research, Princeton University Press, Princeton.

Edgeworth F.Y. (1881), Mathematical Psychics, Kegan, London.

Edgeworth F.Y. (1903) [1970], «Review» to Pareto (1903) [1982], The Economic Journal. Reprinted in Edgeworth (1970), III, pp. 43-47.

Edgeworth F.Y. (1915) [1970], «On some theories due to Pareto, Zawadski, W.E. Johnson and others », The Economic Journal, March-June. Reprinted in Edgeworth (1970), II, pp. 450-491.

Edgeworth F.Y. (1922), «The Mathematical Economics of Professor Amoroso», The Economic Journal, XXXII, pp. 400-407.

Edgeworth F.Y. (1926a), ad vocem «Pantaleoni », Palgrave Dictionary of Political Economy, Vol. 3, pp. 709-10.

Edgeworth F.Y. (1926b), ad vocem «Pareto», Palgrave Dictionary of Political Economy, Vol. 3, pp. 711-12, Macmillan, London.

Edgeworth F.Y. (1970), Papers Related to Political Economy, 3 Voll., Burt Franklin, New York. Reprint of the original edition, 1925.

Elster J. (1986), Rational Choice, Basil Blackwell, Oxford.

Revue européenne des sciences sociales, n. 116.

Faucci R. (1986), «Note su positivismo e pensiero economico in Italia tra Otto e Novecento», Rivista Internazionale di Scienze Economiche e Commerciali, January, pp. 75-94.

Faucci, R. (2000), «Note sull'influenza della cultura economica tedesca in Italia», in V. Gioia and H.D. Kurz (eds), Science, Institutions and Economic Development: the Contribution of «German» economists and the Reception in Italy (1860-1930), Giuffé, Milan, pp. 713-725.

Finioa M. (1980), Il pensiero economico italiano (1850-1950), Cappelli, Bologna. 
Georgescu-Roegen N. (1935), «Note on a proposition on Pareto », Quarterly Journal of Economics, XLIV, pp. 706-714.

Georgescu-Roegen N. (1975), «Vilfredo Pareto and his Theory of Ophelimity», Atti dei Convegni Lincei: Convegno internazionale Vilfredo Pareto, Accademia Nazionale dei Lincei, Rome, pp. 223-265.

Georgescu-Roegen N. (1987), ad vocem «Ophelimity», New Palgrave Dictionary of Political Economy, III, pp. 716-8.

Groenewegen P. (1996), A Soaring Eagle: Alfred Marshall 1842-1924, E. Elgar, Cheltenham.

Guala F. (1998), «Pareto on Idealisation and the Method of Analysis-Synthesis », Social Science Information/Information sur les sciences socials, 37, pp. 23-44.

Hands D.W. (1993), «More Light on Integrability, Symmetry, and Utility as Potential Energy in mirowski's Critical History », Non-Natural Social Science: Reflecting on the Enterprise of More Heat than Light, Annual supplement to volume 25 History of Political Economy, ed. by N. De Marchi, Duke University Press, Durham and London.

Hargreaves-Heap et al. (1992), The Theory of Choice. A Critical Guide, Blakwell, Oxford.

Hausman D.M. (1998), «Problems with Realism in Economics», Economics and Philosophy, 14, pp. 185-216.

Hausman D.M. (1999), «Ontology and Methodology in Economics», Economics and Philosophy, 15, pp. 283-288.

Henderson L.J. (1935), Pareto's General Sociology, Harvard University Press, Cambridge Mass.

Hicks J. R. (1932), Marginal Productivity and the Lausanne School: A Reply, «Economica», 12, pp. 297-300.

Hicks J. R. (1939) [1946], Value and Capital, Oxford University Press, Oxford.

Hicks J.R. (1979), «The formation of an economist», Banca Nazionale del Lavoro Quarterly Review, pp. 355-364.

Hicks J. R. (1981-83), Collected Essays on Economic Theory, Vol. 3, Clarendon Press, Oxford.

Hicks, J., R. Allen (1934), «A Reconsideration of the Theory of Value», Economica, 1, pp. 52-76; 196-219.

Hollis M. (1998), Trust within Reason, Cambridge University Press, Cambridge.

Hollis M., Sugden R. (1993), «Rationality in Action», Mind, January, pp. 1-34.

Hurwicz L. (1971), «On the Problem of Integrability of Demand Functions» in Chipman J. S., Hurvicz L., Richter M. K., Sconneschein H. F. (eds.), Preferences, Utility, and Demand, Harcourt Brace Jovanovich, New York, pp. 174-214.

Ingrao B., Ranchetti F. (1996), Il mercato nel pensiero economico. Storia e analisi di un'idea dall'illuminismo alla teoria dei giochi, Hoepli, Milan.

Ingrao, B., Israel G. (1990), The Invisible Hand, Mit Press, Cambridge Mass.

Jevons S. (1871) [1888], The Theory of Political Economy, Macmillan, London.

Johnson W.E. (1913), «The Pure Thoery of Utility Curves», The Economic Journal, 23, pp. 483-513.

Keynes J. N. (1891) [1963], The Scope and Method of Political Economy, reprint Kelley, New York.

Kirman A. (1987), «Pareto as an Economist», New Palgrave Dictionary of Political Economy, Vol. IV, pp. 804-809.

Kirman A. (1999), «Vilfredo Pareto», in Italian Economist of $20^{\text {th }}$ Century, ed. by F. Meacci, Elgar, Cheltenham.

Lange O. (1934), «The Determinateness of the Utility Function», Review of Economic Studies, 1, pp. 218-225.

Lawson T. (1997), Economics and Reality, Routledge, London.

Lawson T. (1999), «What has Realism got to do with it?», Economics and Philosophy, 15, pp. 269-282.

Lewin S. (1996), «Economics and Psychology: Lessons for Our Own Day from the Early Twentieth Century », Journal of Economic Literature, 34, pp. 1293-1323.

Macchioro A. (1991), Il momento attuale. Saggi etico-politici, Il poligrafo, Milan. 
Magliulo A. (1993), «The reception of Italian economics in England (1915-1945)», Il Pensiero Economico Italiano, I, pp. 7-53.

Malinvaud E. (1993), «Le manuel de Pareto et la théorie moderne des prix », Revue d'économie politique, 103, pp. 157-159.

Marchionatti R., Gambino E. (1997), «Pareto and Political Economy as a Science: Methodology Revolution and Analytical Advances in Economic Theory in the 1890s », Journal of Political Economy, 105, pp. 1322-48.

Marshall A. (1890) [1946], Principles of Economics, Macmillan, London.

Marshall A. (1996), The Correspondence of Alfred Marshall, Economist (1868-1924), ed. by Whitaker, Cambridge University Press, Cambridge.

Mill J.S. (1836) [1967], «On the Definition of Political Economy ad the Method of Investigation Proper to It », in Collected Works of John Stuart Mill, vol. 4, Toronto, University of Toronto Press, 1967.

Mill J.S. (1843) [1862], System of Logic, Ratiocinative and Inductive, Parker, Son, and Bourn, London.

Mill J.S. (1897), Early Essays, George Bell and Sons, London.

Mirowski P. (1989), More Heat than Light: Economics as Social Physics, Psysics as Nature's Economics, CUP, Cambridge.

Montesano A. (1991), «Il massimo di ofelimità per la collettività : definizioni, analisi, interpretazioni di Pareto e loro generalizzazione», in G. Busino (ed by), Pareto oggi, Il Mulino, Bologna, pp. 114-138.

Pantaleoni M. (1898), Pure Economics, English translation of Pantaleoni (1889), Macmillan, London.

Pantaleoni M. (1913) [1925], «Una Prolusione», in Pantaleoni (1925), I, pp. 1-66.

Pantaleoni M. (1923), «Vilfredo Pareto. Obituary», The Economic Journal, XXXIII, pp. 582-590.

Pantaleoni M. (1925), Erotemi di economia, Vol. 2, Laterza, Bari.

Pantaleoni M. (1938), Studi di finanza e statistica, Zanichelli, Bologna.

Pareto V. (1892) [1966], «Les nouvelles théories économiques», Le Monde Economique, JulyAugust-September-October, Euvres Complètes, 9, Droz, Genève.

Pareto V. (1892-93) [1982], «Considerazioni sui principi fondamentali dell'economia pura », Giornale degli Economisti, May, pp. 390-420; June, pp. 485-512; August pp. 119-157, Euvres complètes, 26, Droz, Genève.

Pareto V. (1894) [1966], «Leçon Inaugurale d'écomnomie politique», Euvres Complètes, 9, Droz, Genève.

Pareto V. (1894) [1982], «Teoria matematica dei cambi forestieri», Giornale degli Economisti, pp. 143-73, Euvres Complètes, 26, Geneve, Droz.

Pareto V. (1896-97) [1964], Cours d'économie politique professé à l'Université de Lausanne, 2 vol., Rouge, Lausanne, Euvres complètes, 1, Droz, Genève.

Pareto V. (1896a) [1965], «La Courbe de la Répartition de la Richesse», Université de Lausanne, Recueil Publié par la Faculté de Droit à l'occasion de l'Exposition nationale Suisse, Genève 1896, Euvres Complètes, 8, Droz, Genève.

Pareto V. (1896b) [1965], «La curva delle entrate e le osservazioni del Professor Edgeworth», Giornale degli Economisti, November 1896, Euvres Complètes, 8, Droz, Genève.

Pareto V. (1897) [1965], «Ultima risposta al Prof. Edgeworth», Giornale degli Economisti, March 1897, pp. 219-220, Euvres Complètes, 3, Droz, Genève.

Pareto V. (1897) [1980], «Il compito della sociologia fra le scienze sociali», Rivista italiana di sociologia, July, pp. 45-54, Euvres Complètes, 22, Droz, Genève.

Pareto V. (1898) [1966], Comment se pose le problème de l'économie pure, Mémoire présenté en décembre 1898 à la Societé «Stella» par le professeur V. P., Lausanne (chez l'auteur), CEuvres Complètes, 9, Droz, Genève.

Pareto V. (1899) [1980], «I problemi della sociologia», Rivista italiana di sociologia, marzo, pp. 145157, Euvres Complètes, 22, Droz, Genève. 
Pareto V. (1899), «Recensione» di Vailati (1898), Zeitschrift für Socialwissenschaft, II, pp. 151-2.

Pareto V. (1900) [1953], «Sul fenomeno economico. Lettera a Benedetto Croce», Giornale degli Economisti, 21, pp. 139-162. English translation « On the Economic Phenomenon», International Economic Papers, n. 3, pp. 180-196, Euvres Complètes, 26, Droz, Genève.

Pareto V. (1900) [1982], «Sunto di alcuni capitoli di un nuovo trattato di economia politica del prof. Pareto », Giornale degli Economisti, vol. X, marzo, pp. 216-235; giugno, pp. 511-549, Euvres Complètes, 26, Droz, Genève.

Pareto V. (1901) [1953], «Ancora sul principio economico», Giornale degli Economisti, 23, pp. 13138. English translation «On the Economic Principle. A reply to Professor Croce», International Economic Papers, n. 3, pp. 203-207, Euvres Complètes, 26, Droz, Genève.

Pareto V. (1901-2) [1965], Les Systèmes Socialistes, Euvres Complètes, 5, Droz, Genève.

Pareto V. (1903) [1982], «Anwendungen der Mathematik auf Nationalökonomie», Encyklopädie der mathematischen Wissenschaften mit Einschluss ihrer Anwendungen, Leipzig, Vol. I, n. 7, pp. 1094-1120, Euvres Complètes, 26, Droz, Genève.

Pareto V. (1906) [1971], Manual of Political Economy, Kelley, New York. English translation of the 1909 French edition of the Italian Manuale d'economia politica con una introduzione alla scienza sociale, Società Editrice Libraria, Milan, Euvres complètes, 7, Droz, Genève.

Pareto V. (1906) [1982], «L'ofelimità dei cicli non chiusi», Giornale degli economisti, 33, English translation in Chipman et all (1971), ch. 18, Euvres complètes, 26, Droz, Genève.

Pareto V. (1907) [1980], «L'économie et la sociologie du point de vue scientifique», Rivista di Scientia, Euvres Complètes, 22, Droz, Genève.

Pareto V. (1907) [1982], «L'interpolazione per la ricerca delle leggi economiche», in Giornale degli Economisti, maggio, pp. 377-385; giugno, pp. 423-453, Euvres Complètes, 26, Droz, Genève.

Pareto V. (1907), «Les ‘Antagonismes économiques' de M. Effertz», Le Mouvement socialiste, August-September, pp. 170-178.

Pareto V. (1910) [1982], «L'œuvre scientifique de M. Walras», Gazette de Lausanne, Euvres Complètes, 26, Droz, Genève.

Pareto V. (1911) [1982], «L'économie mathématique», in Encyclopédie des sciences mathématiques pures et appliquées, publiée sous les auspices des Académies des Sciences de Gottingue, de Leipzig, de Munich et de Vienne avec la collaboration de nombreux savants, Paris, GauthierVillars, Tome I, vol. IV, Euvres Complètes, 26, Droz, Genève.

Pareto V. (1913) [1974], «Preface» to Osorio (1913), Euvres Complètes, 16, Droz, Genève.

Pareto V. (1916) [1963], Trattato di sociologia generale, Barbera, Florence. English Translation The Mind and the Society: a Treatise on general Sociology, New York, Dover, Euvres Complètes, 12, Droz, Genève.

Pareto V. (1918) [1980], «Economia sperimentale», Giornale degli Economisti, Euvres Complètes, 22, Droz, Genève.

Pareto V. (1920) [1976], Fatti e teorie, Vallecchi, Florence. French translation in CEuvres Complètes, Vol. 21, Droz, Genève.

Pareto V. (1920) [1980], «Epilogo », CEuvres Complètes, 22, Droz, Genève.

Pareto V. (1921) [1970], Le trasformazioni della democrazia, Corbaccio, Milan, Euvres Complètes, 13, Droz, Genève.

Pareto V. (1960) [1984], Lettere a Maffeo Pantaleoni, ed by G. De Rosa, voll. 3, Banca Nazionale del Lavoro, Rome, Euvres Complètes, 28, Droz, Genève.

Pareto V. (1962), Carteggi Paretiani 1892-1923, a cura di G. de Rosa, Banca Nazionale del Lavoro, Rome.

Pareto V. (1975), Corrispondance: 1890-1923, a cura di G. Busino, Euvres Complètes, 19, Droz, Genève.

Pareto V. (1989), Correspondences, Euvres Complètes, 24, Droz, Genève.

Pareto V. (1999), Vilfredo Pareto. Critical Assessments of Leading Economists, ed by J. Cunningam Wood and M. McLure, Voll. 4, Routledge, London.

Parsons T. (1968), The Structure of Social Action, Free Press, New York. 
Pizzorno A. (1973), «Vilfredo Pareto and the Crisis of Nineteenth-century Science», Social Science Quarterly, 54, pp. 480-90.

Ricci U. (1938), «Pareto on Pure Economics », Review of economic studies, 1, pp. 3-21.

Robbins L. (1932), An Essay on the Nature and Significance of Economic Science, Macmillan, London.

Robbins L. (1933), «Introduction» to Wicksteed (1933).

Robbins L. (1971), Autobiography of an economist, Macmillan, London.

Samuelson P.A. (1938), «A Note on the Pure Theory of Consumer's Behaviour», Economica, 5, pp. 61-71.

Samuelson P.A. (1947), Foundations of Economic Analysis, Harvard University Press, Cambridge Mass.

Samuelson P.A. (1948), «Consumption Theory in Terms of Revealed Preferences», Economica, 15, pp. 243-253.

Samuelson P.A. (1950), «The Problem of Integrability in Utility Theory », Economica, 17, pp. 355-383.

Samuelson P.A. (1974), «Complementarity. An Essay on the 40th Anniversary of the Hicks and Allen Revolution in Demand Theory », Journal of Economic Literature, 12, pp. 1255-89.

Schumpeter J.A. (1949), «Vilfredo Pareto (1848-1923)», Quarterly Journal of Economics, 63, pp. 147-173.

Schumpeter J.A. (1994), History of Economic Analysis, Routledge, London.

Seidl C., Schmidt U. (1997), «Pareto on Intra - and Interpersonal Comparability of Utility », History of Economic Ideas, 5, pp. 19-33.

Sensini G. (1948), Corrispondenza di V. Pareto, Cedam, Padua.

Slutsky E. (1915), «Sulla teoria del bilancio del consumatore», Giornale degli Economisti, 51, pp. 1-26.

Stigler G. J. (1950), «The Developement of Utility Theory: I, II », Journal of Political Economy, 58, pp. 307-327; 373-396.

Sugden R. (1991), «Rational choice: A Survey of Contributions from Economics and Philosophy», The Economic Journal, 101, pp. 751-785.

Vailati, G. (1911), Scritti di Giovanni Vailati, ed by U. Ricci, M. Calderoni e G. Vacca, Seeber-Barth, Lipsia-Florence.

Vailati, G. (1971), Epistolario 1891-1909, ed by G. Lanaro, Einaudi, Turin.

Vailati, G. (1987), Scritti. Opere complete, ed by G. Quaranta, Forni, Bologna.

Volterra V. (1901), «Sui tentativi di applicazione delle matematiche alle scienza biologiche e sociali», Giornale degli Economisti, 23, pp. 436-58.

Volterra V. (1906), «L'economia matematica e il nuovo Manuale del prof. Pareto», Giornale degli Economisti, 33, pp. 296-301. Englih translation in Chipman et al (1971), ch. 17.

Von Neumann J., Morgenstern O. (1944), Theory of Games and Economic Behavior, Princeton University Press, Princeton.

Walras L. (1960), Corrispondence of Léon Walras, a cura di W. Jaffé, North Holland Publishing Company, Amsterdam.

Wicksteed H. P. (1906) [1933], «Review» to Pareto (1971) [1906], The Economic Journal, 16, pp. 553-57.

Wicksteed H.P. (1910) [1933], The Common Sense of Political Economy, Routledge, London.

Wong S. (1978), The Foundations of Paul Samuelson's Revealed Preferences Theory: A Study by the Method of Rational Reconstruction, Routledge, London.

Zanni A. (1991), «Pareto's monologue with Marshall», Quaderni di storia dell'economia politica, IX, pp. 399-423.

Zanni A. (1999), «Pareto in Tuscany. Discontinuities and Premonitory signs of an Economist and Sociologist », Revue Internationale des Sciences Sociales, XXXVII, pp. 119-140. 